\title{
KORELASI KUALITAS SUPERVISI AKADEMIK PENGAWAS SEKOLAH TERHADAP KINERJA GURU DI MI KECAMATAN PRAMBON NGANJUK
}

\author{
UNAISIYAH \\ Pengawas Pendidikan Agama Islam (PPAI) Kec. Prambon Nganjuk
}

\begin{abstract}
Abstrak.
Supervisi yang handal untuk meningkatkan mutu kinerja guru harus terus digalkkan, seiring dengan perkembangan teknologi saat ini. Pengawasan sebagai supervisor sekolah dituntut menjadi figur yang dapat menjadi contoh dan panutan bagi para guru dan para siswa dalam hal pembentukan karakter baik dalam hal disiplin, maupun dalam hal etika dan moral. Terlebih lagi saat ini telah menerapkan kurikulum baru yang berorientasi pada pembentukan karakter siswa. Memberikan pengetahuan tentang etika pergaulan, penanaman nilai-nilai agama, moral, budi pekerti serta etika bagi anak didik, harus terus menerus dilakukan. Hasil penelitian ini adalah: (1) Tingkat keaktifan supervisi akademik pengawas sekolah di MI Kecamatan Prambon Nganjuk adalah baik hal ini dibuktikan dengan fakta empiris dengan indikator pelaksanaan kurikulum yang berlaku. Peningkatan mutu pembelajaran melalui pengembangan model kegiatan pembelajaran, peran serta peserta didik dalam proses pembelajaran secara aktif, kreatif, demokratis, mendidik, memotivasi, mendorong kreatifitas dan dialogis bahwa sebanyak 66 responden yang menjawab baik adalah 27 responden atau (41\%), cukup baik sebanyak 13 responden atau (20\%), kurang baik sebanyak 11 responden atau (17\%), sangat baik 9 responden atau (13\%) dan sangat kurang baik 6 responden atau (9\%). (2) Tingkat kinerja guru di MI Kecamatan Prambon Nganjuk adalah cukup baik dari 66 responden yang menjawab cukup baik adalah 24 responden atau (36\%), kurang baik 20 responden atau (30\%) sangat kurang baik 11 responden atau (17\%), baik 10 responden atau (15\%), sangat baik 1 orang atau (2\%). (3) Korelasi supervisi akademik pengawas sekolah terhadap kinerja guru di MI Kecamatan Prambon Nganjuk adalah kuat, hal ini dibuktikan dengan penghitungan rumus product moment dan regresi linier sederhana bahwa nilai korelasi sebesar $r_{x y}=0,757$ yang berarti terletak antara 0,60 - 0,79 artinya terdapat korelasi yang kuat antara kualitas supervisi akademik dengan kinerja guru.
\end{abstract}

\section{Kata Kunci : Kualitas Supervisi Akademik, Kinerja Guru}

\section{Pendahuluan}

Supervisi yang handal untuk meningkatkan mutu kinerja guru harus terus digalkkan, seiring dengan perkembangan teknologi saat ini. Pengawasan sebagai supervisor sekolah dituntut menjadi figur yang dapat menjadi contoh dan panutan bagi para guru dan para siswa dalam hal pembentukan karakter baik dalam hal disiplin, maupun dalam hal etika dan moral. Terlebih lagi saat ini telah menerapkan kurikulum baru yang berorientasi pada pembentukan karakter siswa. Memberikan pengetahuan tentang etika pergaulan, penanaman nilai- nilai agama, moral, budi pekerti serta etika bagi anak didik, harus terus menerus dilakukan.

Salah satu usaha untuk meningkatkan kinerja guru guru, dilakukan melalui supervisi akademik pengawas sekolah dalam supervisi kinerja guru. Keberadaan pengawas sekolah dapat membantu guru dalam melaksanakan tugasnya, sebab pengawas sekolah yang profesional, salah satunya akan mampu melakukan supervisi terhadap gurugurunya, sehingga diduga akan dapat memperbaiki situasi proses belajar- 
mengajar yang berdampak positif terhadap peningkatan kualitas pendidikan.

Pengawas sekolah merupakan figur yang menjadi contoh dan panutan bagi para guru dan para siswa dalam hal pembentukan karakter baik dalam hal disiplin, maupun dalam hal etika dan moral. Terlebih lagi saat ini telah menerapkan kurikulum baru yang berorientasi pada pembentukan karakter siswa. Memberikan pengetahuan tentang etika pergaulan, penanaman nilai-nilai agama, moral, budi pekerti serta etika bagi anak didik, harus terus menerus dilakukan. Disamping itu diperlukan juga kesiapan mental dan ketangguhan karakter untuk mereduksi dampak negatif dari keterbukaan informasi.

Mengenai permasalahan kinerja guru, beberapa Madrasah Ibtidaiyah Negeri di Kabupaten Nganjuk pada tahun 2015 ini sudah menerapkan kurikulum 2013 sesuai dengan surat Keputusan Direktur Jenderal Pendidikan Islam Nomor: 5114 Tahun 2015 tentang Penetapan madrasah pelaksana kurikulum 2013 Tahun pelajaran 2015-2016 adalah MIN Nanggungan Prambon Nganjuk. MIN Nanggungan Prambon Nganjuk dalam meningkatkan kinerja guru tentu peran pengawas sekolah sebagai supervisor juga semakin berat karena pengawas sekolah berkewajiban untuk membimbing guruguru dan memberikan gambaran tentang kurikulum 2013 tersebut. Disitulah kualitas supervisi yang diberikan pengawas sekolah menjadi penentu kinerja guru dapat meningkat atau tidak.

Faktanya walaupun guru sudah mendapatkan pelatihan mengenai kurikulum tersebut, tetapi realita di lapangan menunjukkan masih banyak guru yang belum sepenuhnya paham kurikulum 2013. Seperti hasil supervisi peneliti ternyata guru-guru di MIN Nanggungan Prambon Nganjuk mengalami kesulitan dalam hal penilaian. Pasalnya, banyak item sebagai penilaian yang harus dilakukan guru. Kemudian selain itu ketidak pahaman guru bisa terlihat dari kebingungan guruguru dalam menyusun Rencana Pelaksanaan Pembelajaran (RPP) yang sesuai dengan kurikulum 2013. Belum lagi masih banyak guru mengalami kebingungan dalam pelaksanaan pembelajaran yang menggunakan pendekatan saintifik.

Di MIN Nanggungngan Prambon Nganjuk permasalahan yang sama juga dialami oleh madrasah lain seperti MIN Tanjungtani Prambon dan MI Miftahul Muna Prambon. Beberapa di MIN dan MIS di kecamatna Prambon para gurunya masih merasa kesulitan dalam menyusun Rencana Pelaksanaan Pembelajaran (RPP) maupun kesulitan dalam menerapkan pendekatan saintifik dalam setiap pembelajarannya. Selain itu tidak aktifnya KKG di Kecamatan Prambon Kabupaten Nganjuk juga menjadi masalah dalam kinerja guru. Sehingga peran pengawas sekolah dirasa cukup penting dalam memberikan penjelasan yang lebih mendalam mengenai kurikulum 2013 Terutama untuk guru-guru yang tidak tergabung dalam KKG.

Kinerja guru memang bukan hanya tercermin dari pemahaman mengenai kurikulum yang sedang diterapkan saat ini. Akan tetapi jika guru ataupun pengawas sekolah tidak memperhatikan permasalahan ini dengan baik, dikhawatirkan kinerja guru tidak akan mengalami perubahan. Pembelajarannya juga hanya akan seperti kurikulumkurikulum terdahulu tanpa ada perubahan yang berarti.

Peneliti juga sempat melakukan observasi ke MIN Nanggungan Prambon Nganjuk, MIN Tanjungtani dan MI Miftahul Muna. Dari observasi tersebut, peneliti menemukan guru tidak memiliki ruang kerja yang cukup memadai. Dikatakan kurang memadai karena kantor guru yang tidak begitu luas tetapi harus dibagi menjadi dua ruang, yakni kantor guru dan perpustakaan. Padahal seharusnya guru memiliki cukup ruang untuk bisa bekerja dengan nyaman.

Jika faktor lingkungan ini tidak diperhatikan dengan baik, dikhawatirkan kinerja guru juga tidak akan berjalan seperti seharusnya. Guru juga akan merasa malas untuk datang ke kantor, guru juga 
tidak akan melaksanakan tugasnya sebagai seorang guru secara maksimal.

Berdasarkan latar belakang permasalahan di atas, peneliti tertarik untuk mengetahui lebih dalam tentang kinerja guru di MI Kecamatan Prambon Kabupaten Nganjuk dengan mengankat judul tesis "Korelasi kualitas supervisi akademik pengawas sekolah terhadap kinerja guru di MI Kecamatan Prambon Nganjuk"

Rumusan masalah dalam tesis ini adalah: bagaimana tingkat keaktifan supervisi akademik pengawas sekolah di MI Kecamatan Prambon Nganjuk, bagaimana tingkat kinerja guru di MI Kecamatan Prambon Nganjuk, adakah korelasi supervisi akademik pengawas sekolah terhadap kinerja guru di MI Kecamatan Prambon Nganjuk.

\section{Kajian Teori}

\section{Konsep Supervisi Akademik}

Supervisi adalah kegiatan yang berupa bimbingan kepada bawahan untuk mengembangkan dan menciptakan pembelajaran yang lebih efektif dan sesuai dengan tujuan yang diharapakan .Sedangkan untuk objek supervisi, maka dapat dikategorikaan sebagai berikut 1) Supervisi akademik atau supervisi pembelajaran, yaitu kegiatan supervisi yang menitik beratkan pengamatan supervisor pada masalah-masalah akademik, yaitu hal-hal yang langsung berada dalam lingkungan kegiatan pembelajaran pada waktu siswa sedang dalam proses mempelajari sesuatu. 2) Supervisi administrasi, yaitu menitik beratkan pengamatan supervisor pada masalah-masalah administrasi yang berfungsi sebagai pendukung dan pelancar terlaksananya pembelajaran. 3) Supervisi lembaga atau supervisi institusional, yaitu pengamatan supervisor pada aspek-aspek yang berada diseluruh sekolah. Jika supervisi akademik menitik untuk meningkatkan kualitas pembelajaran, maka supervise lembaga untuk meningkatkan nama baik sekolah atau kinerja sekolah secara keseluruhan. ${ }^{1}$

\section{Tujuan dan Fungsi Supervisi akademik}

Beberapa tujuan yang didapat dengan diadakannya kegiatan supervisi akademik ada tiga tujuan yaitu: a) Supervisi akademik diselenggarakan dengan maksut membantu guru mengembangkan kemampuan profesionalnya dalam memahami akademik, kehidupan kelas, mengembangkan keterampilan mengajarnya dan menggunakan kemampuannya melalui teknik-teknik tertentu. b) Supervisi akademik diselenggarakan dengan maksut untuk memonitor kegiaan belajar mengajar di sekolah. Kegiatan monitor bisa dilakukan dengan melakukan kunjungan kepala sekolah ke kelas-kelas disaat guru sedang mengajar, percakapan pribadi dengan guru, teman sejawatnya maupun dengan murit-muritnya. c) supervisi akademik diselenggarakan untuk mendorong guru menerapkan kmampuannya dalam melaksanakan tugas-tugas mengajarnya, mendorong guru mengembangkan kemampuannya sendiri, serta mendorong guru agar ia memiliki perhatian yang sungguh-sungguh (commitement) terhadap tugas dan tanggung jawabnya. ${ }^{2}$

Menurut Alfonso, Firth, dan Neville supervisi akademik yang baik adalah supervisi yang mampu berfungsi mencapai multitujuan tersebut di atas. Tidak ada keberhasilan bagi supervisi akademik jika hanya memerhatikan salah satu tujuan tertentu dengan mengesampingkan tujuan lainnya. Hanya dengan merefleksi ketiga tujuan inilah supervisi akademik akan berfungsi mengubah perilaku mengajar guru. Pada gilirannya nanti perubahan perilaku guru ke arah yang lebih

1 Iskandar, Urai, Macam-macam supervisi. https://uray-iskandar.blogspot.com, diakses pada 14 Maret 2016, jam 18:30 WIB.

2 Asf, Jasmani, (2013), Supervisi Pendidikan h. 36 
berkualitas akan menimbulkan perilaku belajar murid yang lebih baik. ${ }^{3}$

\section{Kinerja Guru}

Akadum mendefinisikan kinerja adalah hasil kerja yang secara kualitas dan kuantitas yang dicapai oleh seorang pegawai dalam melaksanakan tugasnya sesuai dengan tanggung jawab yang diberikan kepadanya. ${ }^{4}$ Sulistiyani dan Rosidah sebagaimana yang dikutip AKadum menyatakan kinerja seseorang merupakan kombinasi dari kemampuan, usaha, dan kesempatan yang dapat dinilai dari hasil kerjanya. ${ }^{5}$ Secara definitif Bernandin dan Russell dalam Akadum, juga mengemukakan kinerja adalah suatu hasil kerja yang dicapai seseorang dalam melaksanakan tugas-tugas yang dibebankan kepadanya yang didasarkan atas kecakapan, pengalaman, dan kesungguhan, serta waktu. $^{6}$ Penilaian kinerja adalah menilai rasio hasil kerja nyata dari standar kualitas maupun kuantitas yang dihasilkan setiap karyawan. ${ }^{7}$ Menurut Andrew F. Sikula dalam Hasibuan penilaian kinerja adalah evaluasi yang sistematis terhadap pekerjaan yang telah dilakukan oleh karyawan dan ditujukan untuk pengembangan. ${ }^{8}$

Dale Yoder dakan Hasibuan mendefinisikan penilaian kinerja sebagai prosedur yang formal dilakukan di dalam organisasi untuk mengevaluasi pegawai dan sumbangan serta kepentingan bagi pegawai.9. Sedangkan menurut Siswanto

3 Alfonso, RJ., Firth, G.R., dan Neville, R.F. (2001) Instructional Supervision, A Behavior System, Boston: Allyn and Bacon, Inc, h. 21

4 Akadum. (1999). Potret Guru Memasuki Milenium Ketiga. Suara Pembaharuan. (Online).(http://www.suarapembaharuan.com/New s/1999/01/220199/OpEd, diakses 21 Maret 2016). h. 67

5 Ibid., h. 67

6 Ibid., h. 67

7 Hasibuan, H. Malayu S. P. (2005). Manajemen Sumber Daya Manusia. Jakarta: PT. Bumi Aksara, h. 87

8 Ibid., h. 88

9 Ibid., h. 25 penilaian kinerja adalah suatu kegiatan yang dilakukan manajemen atau penyelia. Penilai untuk menilai kinerja tenaga kerja dengan cara membandingkan kinerja atas kinerja dengan uraian atau deskripsi pekerjaan dalam suatu periode tertentu biasanya setiap akhir tahun. ${ }^{10}$

Berdasarkan pengertian tentang kinerja di atas dapat disimpulkan bahwa kinerja adalah hasil atau taraf kesuksesan yang dicapai seseorang dalam bidang pekerjaannya menurut kriteria tertentu dan dievaluasi oleh orang-orang tertentu terutama atasan pegawai yang bersangkutan.

Tujuan Penilaian kinerja sangat bermanfaat bagi dinamika pertumbuhan organisasi secara keseluruhan. Melalui penilaian tersebut, maka dapat diketahui bagaimana kondisi riil pegawai dilihat dari kinerja dan dapat dijadikan sebagai bahan pertimbangan dalam pengambilan keputusan.

Kinerja (performance) merupakan aktivitas seseorang dalam melaksanakan tugas pokok yang dibebankan kepadanya. Pelaksanaan tugas dan tanggung jawab tersebut merupakan pengekspresian seluruh potensi dan kemampuan yang dimiliki seseorang serta menuntut adanya kepemilikan yang penuh dan menyeluruh. Dengan demikian, munculnya kinerja seseorang merupakan akibat dari adanya suatu pekerjaan atau tugas yang dilakukan dalam kurun waktu tertentu sesuai dengan profesi dan job deskcription individu yang bersangkutan. Sebutan guru dapat menunjukkan suatu profesi atau jabatan fungsional dalam bidang pendidikan dan pembelajaran, atau seseorang yang menduduki dan melaksanakan tugas dalam bidang pendidikan dan pembelajaran.

\section{Faktor yang Mempengaruhi Kinerja Guru}

Kinerja Guru akan menjadi optimal, bilamana diintegrasikan dengan komponen sekolah baik kepala sekolah, fasilitas kerja,

10 Siswanto. (2003). Manajemen Tenaga Kerja Indonesia Pendekatan Administratif dan Operasional Jakarta: Bumi Aksara, h. 25 
guru, karyawan, maupun anak didik. Menurut Pidarta bahwa ada beberapa faktor yang dapat mempengaruhi kinerja guru dalam melaksanakan tugasnya yaitu : 1). Kepemimpinan kepala sekolah, 2). Fasilitas kerja, 3). Harapan-harapan, dan 4.) Kepercayaan personalia sekolah. Dengan demikian nampaklah bahwa kepemimpinan kepala sekolah dan fasilitas kerja akan ikut menentukan baik buruknya kinerja guru. ${ }^{11}$

Selain itu, tingkat kualitas kinerja guru di sekolah memang banyak faktor yang turut mempengaruhi, baik faktor internal guru yang bersangkutan maupun faktor yang berasal dari guru seperti fasilitas sekolah, peraturan dan kebijakan yang berlaku, kualitas manajerial dan kepemimpinan kepala sekolah, dan kondisi lingkungan lainnya. Tingkat kualitas kinerja guru ini selanjutnya akan turut menentukan kualitas lulusan yang dihasilkan serta pencapaian lulusan yang dihasilkan serta pencapaian keberhasilan sekolah secara keseluruhan. ${ }^{12}$.

Faktor-faktor Penyebab Rendahnya Profesionalisme Guru dalam pendidikan nasional kita memang tidak secerah di negara-negara maju. Baik institusi maupun isinya masih memerlukan perhatian ekstra pemerintah maupun masyarakat. Dalam pendidikan formal, selain ada kemajemukan peserta, institusi yang cukup mapan, dan kepercayaan masyarakat yang kuat, juga merupakan tempat bertemunya bibit-bibit unggul yang sedang tumbuh dan perlu penyemaian yang baik. Pekerjaan penyemaian yang baik itu adalah pekerjaan seorang guru. Jadi guru memiliki peran utama dalam sistem pendidikan nasional khususnya dan kehidupan kita umumnya.

\section{Pengaruh Kualitas Supervisi Akademik terhadap Kinerja Guru}

Para pakar pendidikan telah banyak menegaskan bahwa seseorang akan

11 Lamatenggo, (2001). Kinerja Guru: Korelasi antara Persepsi Guru terhadap Perilaku Kepemimpinan Kepala Sekolah, Motivasi Kerja dan Kinerja Guru SD di Gorontalo" . Jakarta: Universitas Negeri Jakarta." Tesis 12 Ibid., bekerja secara profesional apabila ia memiliki kompetensi yang memadai. Maksudnya adalah seseorang akan bekerja secara profesional apabila ia memiliki kompetensi secara utuh. Seseorang tidak akan bisa bekejra secara profesional apabila ia hanya memenuhi salah satu kompetensi di antara sekian kompetensi yang dipersyaratkan.

Kompetensi tersebut merupakan perpaduan antara kemampuan dan motivasi. Betapapun tingginya kemampuan seseorang, ia tidak akan bekerja secara profesional apabila ia tidak memiliki motivasi kerja yang tinggi dalam mengerjakan tugas-tugasnya. Sebaliknya, betapapun tingginya motivasi kerja seseorang, ia tidak akan bekerja secara profesional apabila ia tidak memiliki kemampuan yang tinggi dalam mengerjakan tugas-tugasnya. Selaras dengan penjelasan ini adalah satu teori yang dikemukakan oleh Glickman menurutnya ada empat prototipe guru dalam mengelola proses pembelajaran. Proto tipe guru yang terbaik, menurut teori ini, adalah guru prototipe profesional. Seorang guru bisa diklasifikasikan ke dalam prototipe profesional apabila ia memiliki kemampuan tinggi (high level of abstract) dan motivasi kerja tinggi (high level of commitment). ${ }^{13}$

Penjelasan di atas memberikan implikasi khusus kepada apa seharusnya program supervisi akademik. Supervisi akademik yang baik harus mampu membuat guru semakin kompeten, yaitu guru semakin menguasai kompetensi, baik kompetensi kepribadian, kompetensi pedagogik, kompetensi professional, dan kompetensi sosial. Oleh karena itu supervisi akademik harus menyentuh pada pengembangan seluruh kompetensi guru. Sehubungan dengan pengembangan kedua dimensi ini, menurut Neagley terdapat dua aspek yang harus menjadi perhatian supervisi akademik baik dalam

${ }^{13}$ Asf, Jasmani, (2013), Supervisi Pendidikan 
perencanaannya, pelaksanaannya, maupun penilaiannya. ${ }^{14}$

Pertama, apa yang disebutkan dengan substantive aspects of professional development (yang selanjutnya akan disebut dengan aspek substantif). Aspek ini menunjuk pada kompetensi guru yang harus dikembangkan melalui supervisi akademik. Aspek ini menunjuk pada kompetensi yang harus dikuasai guru. Penguasaannya merupakan sokongan terhadap keberhasilannya mengelola proses pembelajaran.

Ada empat kompetensi yang harus dikembangkan melalui supervisi akademik, yaitu yaitu kompetensi-kompetensi kepribadian, pedagogik, professional, dan sosial. pemahaman dan pemilikan guru terhadap tujuan akademik, persepsi guru terhadap murid, pengetahuan guru tentang materi, dan penguasaan guru terhadap teknik. Aspek substansi pertama dan kedua merepresentasikan nilai, keyakinan, dan teori yang dipegang oleh guru tentang hakikat pengetahuan, bagaimana muridmurid belajar, penciptaan hubungan guru dan murid, dan faktor lainnya. Aspek substansi ketiga merepresentasikan seberapa luas pengetahuan guru tentang materi atau bahan pelajaran pada bidang studi yang diajarkannya. Adapun aspek substansi keempat merepresentasikan seberapa luas penguasaan guru terhadap teknik akademik, manejemen, pengorganisasian kelas, dan keterampilan lainnya yang merupakan unsur akademik yang efektif.

Kedua, apa yang disebut dengan professional development competency areas (yang selanjutnya akan disebut dengan aspek kompetensi). Aspek ini menunjuk pada luasnya setiap aspek substansi. Guru tidak berbeda dengan kasus profesional lainnya. Ia harus mengetahui bagaimana mengerjakan (know how to do) tugastugasnya. Ia harus memiliki pengetahuan tentang bagaimana merumuskan tujuan akademik, murid-muridnya, materi pelajaran, dan teknik akademik. Tetapi, mengetahui dan memahami keempat aspek substansi ini belumlah cukup. Seorang guru harus mampu menerapkan pengetahuan dan pemahamannya. Dengan kata lain, ia harus bisa mengerjakan (can do).

Selanjutnya, seorang guru harus mau mengerjakan (will do) tugas-tugas berdasarkan kemampuan yang dimilikinya. Percumalah pengetahuan dan keterampilan yang dimiliki oleh seorang guru, apabila ia tidak mau mengerjakan tugas-tugasnya dengan sebaik-baiknya. Akhirnya seorang guru harus mau mengembangkan (will grow) kemampuan dirinya sendiri.

Sedangkan bilamana merujuk kepada Undang-Undang Nomor 14 Tahun 2005 Tentang Guru dan Dosen, ada empat kompetensi yang harus dimiliki oleh seorang guru dan harus dijadikan perhatian utama kepala sekolah dalam melakukan supervisi akademik, yaitu kompetensi-kompetensi kepribadian, pedagogik, professional, dan sosial Supervisi akademik yang baik adalah supervisi yang mampu menghantarkan guru-guru menjadi semakin kompeten.

Kinerja seseorang merupakan hal yang kompleks dan terpadu yang keberhasilannya dipengaruhi beberapa faktor, baik faktor internal maupun external. Menurut Keith Davis dalam Wibowo menyatakan faktor-faktor yang mempengaruhi kinerja adalah kemampuan (ability=knowledge +skill) dan motivasi (motivation $=$ attitude + situation $)$. Ada tiga faktor situasional yang mempengaruhi kinerja, yaitu abilities and skill, rolr perception dan effort or motivation. Masalah kinerja selalu mendapat perhatian dalam manajemen karena sangat menekankan pengertian sebagai hasil atau apa yang dikeluarkan dari sebuah pekerjaan dan kontribusi pada produktivitas lembaga atau organisasi. ${ }^{15}$
14 Neagley, R.L. and Evans, N.D. (1980). Handbook for Effective Supervision of Instruction. Eng leys wood cliff, New Jersey : Prentice-Hall, Inc, h. 81
15 Wibowo (2004) Manajemen Kinerja, Jakarta : Rajawali Press, h. 43 
Hasil penelitian

\section{Tingkat Keaktifan Supervisi Akademik Pengawas Sekolah di MI Kecamatan Prambon Nganjuk}

Berdasarkan data penelitian menunjukan bahwa sebagian besar responden yaitu 27 responden (41\%) menyatakan bahwa kualitas supervisi akademik yang diberikan oleh pngawas sekolah sudah baik sehingga dapat diasumsikan akan mempunyai korelasi besar terhadap kinerja guru di MI se Kecamatan Prambon kabupaten Nganjuk. Sedangkan 9 responden (12\%) menganggap bahwa kualitas supervisi pengawas sekolah sudah sangat baik sedangkan responden yang lainnya menganggap bahwa supervisi pengawas sekolah sangat kurang baik, baik dan cukup baik. Dari data tersebut membuktikan bahwa perjalanan profesi pengawas dan kepengawasan sekolah/ madrasah tampaknya masih perlu ditegakkan dan dikembangkan lebih jauh lagi. Berbagai persoalan masih menyelimuti nasib profesi yang disebut-sebut sebagai tenaga penjaminan mutu pendidikan ini. Sebenarnya eksistensi pengawas sekolah dinaungi oleh sejumlah dasar hukum.Undang-undang Republik Indonesia Nomor 20 Tahun 2003 dan Peraturan Pemerintah Nomor 19 Tahun 2005 adalah landasan hukum yang terbaru yang menegaskan keberadaan pejabat fungsional itu. Selain itu, Keputusan Menteri Pendayagunaan Aparatur Negara Nomor 21 Tahun 2010 merupakan menetapan pengawas sebagai pejabat fungsional dan angka kreditnya. Jika ditilik sejumlah peraturan dan perundangundangan yang ada, yang terkait dengan pendidikan, ternyata secara hukum pengawas sekolah tidak diragukan lagi keberadaannya. Dengan demikian, tidak ada alasan apapun dan oleh siapapun yang memarjinalkan dan mengecilkan eksistensi pengawas sekolah.

Masalah dalam pengawasan terkait langsung dengan tugas pokok Pengawas sekolah/madrasah. Menurut Peraturan Menteri Pendayaan Aparatur Negara dan Reformasi Birokrasi nomor 21 Tahun 2010 tentang Jabatan Fungsional Pengawas sekolah/madrasah dan Angka Kreditnya, tugas pokok Pengawas sekolah/madrasah adalah melaksanakan tugas pengawasan akademik dan manajerial pada satuan pendidikan yang meliputi penyusunan program pengawasan, pelaksanaan pembinaan, pemantauan pelaksanaan 8 (delapan) standar Nasional Pendidikan, penilaian, pembimbingan, dan pelatihan profesional guru, evaluasi hasil pelaksanaan program pengawasan, dan pelaksanaan tugas kepengawasan di daerah khusus.

Berdasarkan analisis hasil penelitian menunjukan bahwa aktivitas supervisi akademik yang dilakukan oleh pengawas sekolah lebih menekankan pada penilaian dan pembinaan professional kinerja guru terkait dengan kemampuan guru dalam membuat perencanaan program pembelajaran, prosedur pembelajaran, hubungan inter-personal guru dan siswa, dan peningkatan kemampuan (ability dan Skills) guru secara umum. Kegiatan supervisi akademik yang dilakukan oleh pengawas disamping untuk membantu kebutuhan guru secara rutin, juga sering dilakukan dengan maksud untuk menilai kinerja guru yang akan diusulkan angka kredit kenaikan pangkat, yang akan di sertifikasi atau pada guru-guru yang sudah disertifikasi untuk diusulkan tunjangan profesinya.

Informasi ini penting untuk diungkapkan karena pada prinsifnya supervisi akademik adalah upaya memberi bantuan atau pembinaan terhadap kekurangan, kelemahan atau kesulitan yang dialami guru dalam pelaksanaan pembelajaran sehingga core business pendidikan dapat tercapai dengan efektif dan efisien. Identifikasi permasalah yang dihadapi guru dalam menjalankan tugas proses kegiatan pembelajaran di kelas (Edukasi ) akan menyangkut lima hal yaitu ; (1) dalam perencanan program pembelajaran, (2) prosedur pembelajaran, (3) strategi pembelajaran, (4) hubungan 

terhadap Kinerja Guru...

Oleh: Unaisiyah

inter-personal, dan

(5) media pembelajaran. ${ }^{16}$

\section{Tingkat Kinerja Guru di MI Kecamatan Prambon Nganjuk}

Berdasarkan analisis hasil penelitian menunjukan bahwa tingkat kinerja guru di MI se Kecamatan Prambon Kabupaten Nganjuk adalah cukup baik karena sebanyak 24 orang responden atau (36\%) menganggap bahwa kinerja guru di MI se Kecamatan cukup baik.

Kinerja baik secara individu maupun organisasi mempunyai peran yang besar dalam keberlangsungan organisasi, jika dalam hal ini kinerja guru sudah cukup baik maka kualitas pembelajaran yang diberikan kepada siswa juga akan baik sehingga hasilnya kemampuan belajar siswa juga akan baik. Tujuan pembelajaran pada hakikatnya adalah perubahan tingkah laku pada diri siswa. Oleh sebab itu dalam penilaian hendaknya diperiksa sejauh mana perubahan tingkah laku siswa telah terjadi melalui proses belajarnya. Dengan mengetahui tercapai tidaknya tujuan pembelajaran, dapat diambil tindakan perbaikan proses pembelajaran dan perbaikan siswa yang bersangkutan. Misalnya dengan melakukan perubahan dalam strategi mengajar, memberikan bimbingan dan bantuan belajar kepada siswa.

Dengan perkataan lain, hasil penilaian tidak hanya bermanfaat untuk mengetahui tercapai tidaknya perubahan tingkah laku siswa, tetapi juga sebagai umpan balik bagi upaya memperbaiki proses pembelajaran. Oleh sebab itu, penilaian hasil dan proses belajar saling berkaitan satu sama lain sebab hasil belajar yang dicapai siswa merupakan akibat dari proses pembelajaran yang ditempuhnya (pengalaman belajarnya). Sejalan dengan pengertian diatas maka fungsi penilaian adalah sebagai berikut: (a) alat untuk mengetahui tercapai-tidaknya tujuan pembelajaran, (b) umpan balik bagi perbaikan proses pembelajaran,dan (c)

16 Surya Dharma (2010). Manajemen Kinerja. Edisi ketiga. Pustaka Pelajar: Yogyakarta, h. 14 dasar dalam menyusun laporan kemajuan belajar siswa kepada para orang tuanya. Dengan demikian mengacu kepada fungsi diatas maka jenis penilaian yang bervariatif perlu dilakukan oleh guru.

Dari segi alatnya, penilaian hasil belajar dapat dibedakan menjadi dua yaitu berupa tes dan bukan tes (non-test). Tes bisa terdiri atas tes lisan ( menuntut jawaban secara lisan), tes tulisan (menuntut jawaban secara tulisan), dan tes tindakan (menuntut jawaban dalam bentuk perbuatan). Sedangkan bukan tes (non test) sebagai alat penilaian mencakup observasi, kuesioner, wawancara, skala penilaian, sosiometri, dan studi kasus, ${ }^{17}$

Tes hasil belajar ada yang sudah dibakukan (standardized test), ada pula yang dibuat guru, yakni tes yang tidak baku. Pada umumnya penilaian hasil belajar di sekolah menggunakan tes buatan guru untuk semua bidang studi/mata pelajaran. Tes baku, sekalipun lebih baik dari pada tes buatan guru, masih sangat langka sebab membuat tes baku memerlukan beberapa kali percobaan dan analisis dari segi reliabilitas dan validitasnya. Kemampuan seorang guru didalam melakukan penilaian kemajuan belajar siswa dapat tercermin dari sejauhmana pemahaman dan penerapan konsep penilaian dalam praktek proses pembelajaran sehari-hari, sehingga dalam kontek ini bisa dijadikan salah satu indikator professional kinerja guru.

Standar Penilaian Acuan Norma (PAN) memilki keuntungan dan kelemahan, keuntungannya adalah dapat diketahui prestasi kelompok atau kelas sekaligus dapat diketahui keberhasilan pembelajaran bagi semua siswa. kelemahannya adalah kurang meningkatkan kualitas hasil belajar. Jika nilai rata-rata kelompok atau kelasnya rendah, misalnya skor 40 dari seratus, maka siswa yang memperoleh nilai 45 (di atas rata-rata) sudah dikatakan baik, atau dinyatakan lulus, sebab berada di atas ratarata kelas, padahal skor 45 dari maksimum

17 Nana Sudjana. (2003). Penilaian Hasil Proses Belajar Mengajar, h. 23 
skor 100 termasuk rendah. Sedangkan Penilaian Acuan Patokan (PAP) mengacu pada tujuan pembelajaran atau kompetensi yang harus dikuasai siswa, derajat keberhasilan siswa dibandingkan dengan tujuan atau kompetensi yang seharusnya dicapai atau dikuasai siswa bukan dibandingkan dengan prestasi kelompoknya. Dalam penilaian ini ditetapkan kriteria minimal harus dicapai atau dikuasai siswa. Kriteria minimal yang biasa digunakan adalah $80 \%$ dari tujuan atau kompetensi yang seharusnya dikuasai siswa. Makin tinggi kriteri-anya makin baik mutu pendidikan yang dihasilkan.

Kegiatan pembelajaran di kelas adalah inti penyelenggaraan pendidikan yang ditandai oleh adanya kegiatan pengelolaan kelas, penggunaan media dan sumber belajar, dan penggunaan metode serta strategi pembejaran. Semua tugas tersebut merupakan tugas dan tanggung jawab guru yang secara optimal dalam pelaksanaanya menuntut kemampuan guru. Guru diharapkan mampu memilih dan menggunakan metode pembelajaran sesuai dengan materi yang akan disampaikan, seperti yang dikemukakan oleh Suyanto yang menyatakan bahwa: Setiap metode pembelajaran memiliki kelebihan dan kelemahan dilihat dari berbagai sudut, namun yang penting bagi guru metode manapun yang digunakan harus jelas tujuan yang akan dicapai ${ }^{18}$

Karena siswa memiliki interes yang sangat heterogen idealnya seorang guru harus menggunakan multi metode, yaitu memvariasikan penggunaan metode pembelajaran di dalam kelas seperti metode ceramah dipadukan dengan Tanya jawab dan penugasan atau metode diskusi dengan pemberian tugas dan seterusnya. Hal ini dimaksudkan untuk menjembatani kebutuhan siswa akan pengalaman pembelajaran, dan menghindari terjadinya kejenuhan yang dialami siswa Menurut Akadum menyatakan bahwa:

Peristiwa belajar mengajar terjadi apabila subjek didik secara aktif

Efektif, h. 74 berinteraksi dengan lingkungan belajar yang diatur oleh guru. Proses belajar mengajar yang efektif memerlukan strategi dan media atau teknologi pendidikan yang tepat. ${ }^{19}$

Jadi proses belajar mengajar yang efektif ditandai dengan adanya sejumlah keterampilan guru dalam hal; pengelolaan kelas, memilih materi pembelajaran yang relevan, melilih metode dan strategi pembelajaran yang bervariatif, menggunakan media dan teknologi pembelajaran yang memberikan pengalaman pembelajaran bagi siswa, serta berlangsung dengan suasana yang menyenangkan.

Evaluasi hasil belajar, Informasi ini sangat strategis untuk dikemukakan, mengingat penilaian hasil belajar adalah kegiatan atau cara yang ditujukan untuk mengetahui tercapai atau tidaknya tujuan pembelajaran dan juga proses pembelajaran yang telah dilakukan. Pada tahap ini seorang guru dituntut memiliki kemampuan dalam menentukan pendekatan dan cara-cara evaluasi, penyusunan alat-alat evaluasi, pengolahan, dan penggunaan hasil evaluasi untuk perbaikan mutu pembelajaran . Indikasi kemampuan guru dalam penyusunan alatalat tes ini dapat digambarkan dari frekuensi penggunaan bentuk alat-alat tes secara variatif, karena alat-alat tes yang telah disusun pada dasarnya digunakan sebagai alat penilaian hasil belajar. Di samping pendekatan penilaian dan penyusunan alat-alat tes, hal lain yang harus diperhatikan guru adalah pengolahan dan penggunaan hasil belajar.

Tes lisan adalah soal tes yang diajukan dalam bentuk pertanyaan lisan dan langsung dijawab oleh siswa secara lisan. Tes ini umumya ditujukan untuk mengulang atau mengetahui pemahaman siswa terhadap materi pelajaran yang telah disampaikan sebelumnya.Tes perbuatan adalah tes yang dilakukan guru kepada siswa. Dalam hal ini siswa diminta melakukan atau memperagakan sesuatu

19 Akadum. (1999). Potret Guru Memasuki Milenium Ketiga, h. 84 
perbuatan sesuai dengan materi yang telah diajarkan seperti pada mata pelajaran kesenian, keterampilan, olahraga, komputer, dan sebagainya.

Kemampuan (ability) guru, adalah sejumlah keahlian yang dimiliki guru terkait dalam proses pembelajaran meliputi ; kemampuan bertanya, penguatan, keterampilan menjelaskan, menutup membuka pembelajaran. Informasi ini penting dikemukakan mengingat, dalam proses pembelajaran, bertanya memainkan peranan penting, hal ini dikarenakan pertanyaan yang tersusun dengan baik dan teknik melontarkan pertanyaan yang tepat akan memberika dampak positif terhadap siswa.

Pertanyaan yang baik menurut Uzer Usman adalah:

(a). Jelas dan mudah dimengerti oleh siswa, (b) Berikan informasi yang cukup untuk menjawab pertanyaan, (c). Difokuskan pada suatu masalah atau tugas tertentu, (d) Berikan waktu yang cukup kepada siswa untuk berpikir sebelum menjawab pertanyaan, (e) Berikan pertanyaan kepada seluruh siswa secara merata, (f) Berikan respon yang ramah dan menyenangkan sehingga timbul kebera-nian siswa untuk menjawab dan bertanya, (g) Tuntunlah jawaban siswa sehingga mereka dapat menemukan sendiri jawaban yang benar. ${ }^{20}$

Dalam proses pembelajaran, bertanya memainkan peranan penting, hal ini dikarenakan pertanyaan yang tersusun dengan baik dan teknik melontarkan pertanyaan yang tepat akan memberikan dampak positif terhadap siswa, yiatu: Meningkatkan pastisipasi siswa dalam kegiatan pembelajaran, Membangkitkan minat dan rasa ingin tahu siswa terhadap sesuatu masalah yang sedang dibicarakan, Mengembangkan pola fikir dan cara belajar aktif dari siswa, karena pada hakikatnya berpikir itu sendiri sesungguhnya adalah bertanya, dan Menuntun proses berpikir

20 Uzer Usman, (2003), Menjadi Guru Profesional, Bandung: Rosda Karya, h. 82 siswa, sebab pertanyaan yang baik akan membantu siswa agar dapat menentukan jawaban yang baik.

Keterampilan bertanya (Questioning skills) yang dimiliki oleh Seorang guru merupakan ciri profesional kinerja seorang guru dalam ngka menciptakan suatu proses pembelajaran siswa yang berkualitas. Memberikan Penguatan, Informasi ini sangat penting untuk diungkapkan, mengingat dalam proses pembelajran pada hakikatnya merupakan proses interaksi antara guru dan siswa secara harmonis, selaras dan terjadi komunikasi secara dua arah ,Surya Dharma, menjelaskan:

Penguatan adalah segala bentuk respon apakah bersifat verbal (diungkapkan dengan kata-kata langsung seperti: bagus, pintar, ya, betul, tepat se-kali, dan sebagainya), maupun nonverbal (biasanya dilakukan dengan gerak, isyarat, pendekatan, dan sebagainya). ${ }^{21}$

Penguatan merupakan bagian dari modifikasi tingkah laku guru terhadap tingkah laku siswa yang bertujuan untuk memberikan informasi atau umpan balik (feedback) bagi siswa atas perbuatannya sebagai suatu tindak, dorongan, atau koreksi. Penguatan dapat berarti juga respon terhadap suatu tingkah laku yang dapat meningkatkan kemungkinan berulangnya kembali tingkah laku tersebut. Tindakan tersebut dimaksudkan untuk memberikan ganjaran atau membesarkan hati siswa agar mereka lebih giat berpartisipasi dalam interaksi pembelajaran. Dengan demikian tujuan dari pemberian penguatan (Reinforcement Skills) ini adalah untuk: Meningkatkan perhatian siswa terhadap pembelajaran, merangsang dan meningkatkan motivasi belajar, meningkatkan kegiatan belajar dan membina tingkah laku siswa yang produktif.

Keterampilan menjelaskan (Explaning skills) dalam pembelajaran adalah penyajian informasi secara lisan yang diorganisasi secara sistematis untuk

${ }^{21}$ Surya Dharma (2010). Manajemen Kinerja 
menunjukkan adanya hubungan yang satu dengan lainnya, misalnya sebab dan akibat. Penyampaian informasi yang terencana dengan baik dan disajikan dengan urut-an yang cocok merupakan ciri utama kegiatan menjelaskan. Tujuan pemberian penjelasan dalam pembelajaran adalah: (1) membimbing siswa untuk dapat memahami konsep, hukum, dalil, fakta, dan prinsip secara objektif dan bernalar; (2) melibatkan siswa untuk berfikir dengan memecahkan masalah-masalah atau pertanyaan; (3) mendapatkan balikan dari siswa mengenai tingkat pemahamannya dan untuk mengatasi kesalahpaham-an siswa; dan (4) membimbing siswa untuk menghayati dan mendapat proses penalaran dan menggunakan bukti-bukti dalam memecahkan masalah. Penyampaian informasi yang terencana dengan baik dan disajikan dengan urutan yang cocok merupakan ciri utama kegiatan menjelaskan. Dengan demikian pemberian penjelasan merupakan aspek yang sangat penting dari kegiatan guru dalam berinteraksi dengan siswa di dalam kelas.

Membuka pelajaran (set insuction) adalah usaha atau kegiatan yang dilakukan oleh guru dalam kegiatan pembelajaran untuk menciptakan prakondisi bagi siswa agar mental maupun perhatiannnya terpusat pada apa yang akan dipelajarinya, sehingga usaha tersebut akan memberikan efek yang positif terhadap kegiatan belajar.

Menutup pelajaran (closure) adalah kegiatan yang dilakukan oleh guru untuk mengakhiri kegiatan pembelajaran. Kegiatan ini dimaksudkan untuk memberikan gambaran menyeluruh tentang apa yang telah dipelajari oleh siswa, mengetahui tingkat pencapaian siswa dan tingkat keberhasilan guru dalam proses pembelajaran.

Strategi merupakan usaha untuk memperoleh kesuksesan dan keberha-silan dalam mencapai tujuan. Dalam dunia pendidikan strategi dapat diartikan sebagai a plan, method, or series of activities designed to achieves a particular educational goal (Surya Dharma, 2008:3). Strategi pembinaan kinerja dapat diartikan sebagai perencanaan yang berisi tentang rangkaian kegiatan yang didesain untuk mencapai tujuan pendidikan tertentu. Dalam hal ini terciptanya suatu profesional kinerja guru dalam penguasaan dan implementasi kompetensi pedagogis khususnya dalam proses pembelajaran siswa di kelas yang lebih berkualitas. Stratgi yang digunakan diantaranya: Insentif berbasis kinerja, KKG dan In-house trainning.

Insentif berbasis kinerja, Informasi ini penting untuk diungkapkan mengingat faktor biaya atau upah sangat berpengaruh terhadap motivasi bagi guru untuk giat dan semangat dalam menjalankan tugas yang dibebankan kepadanya. Konsep Insentif berbasis kinerja dipandang tepat untuk dijalankan di sekolah, mengingat sesuai dengan PP nomor 48 tahun 2008 tentang pengaturan dana pendidikan dalam kontek Wajib belajar Sembilan tahun, dimana Dana Bantuan Oprasional (BOS) , tidak lagi diberikan dalam bentuk honor jumlah jam mengajar kepada guru yang bersetatus PNS. Tetapi penghargaan atau imulemen kepada guru yang bersetatus PNS harus diberikan dalam bentuk insentif yang berbasis kinerja, artinya anggaran dikeluarkan harus berdasarkan program kerja yang ditujukan untuk mendukung tercapainya" Core Buisness Pendidikan" yaitu terciptanya pelayanan proses pembelajaran yang berkualitas. Dengan demikian dalam implementasinya tentu saja akan sangat tergantung kepada kepiawaian dan kreatifitas pihak pengelola yaitu kepala sekolah, yang tercermin dalam program: rencana kerja anggaran Sekolah (RKAS). Dengan konsep ini semua prangkat administrasi perencanaan persiapan pembelajaran seperti; Prota, Prosem, Pemetaan SK,KD, KKM,Silabus RPP, penilaian, remedial dan pengayaan semuanya dibuat dan dilengkapi oleh guru. Dalam proses pembelajaran guru akan berusaha membuat alat perga pembelajaran karena setiap karya akan mendapat insentif. 


\section{Korelasi Supervisi Akademik Pengawas Sekolah Terhadap Kinerja Guru di MI Kecamatan Prambon Nganjuk}

Berdasarkan uji hipotesis bahwa nilai korelasi supervisi akademik pengawas sekolah terhadap kinerja guru di MI sekecamatan Prambon adalah sebesar 0,757 hal ini apabila mengacu pada tabel interpretasi $r$ product moment dapat kita ketahui bahwa interpretasi terhadap Rxy = 0,757 yang berarti terletak antara $0,60-$ 0,79 artinya terdapat korelasi yang kuat antara kualitas supervisi akademik dengan kinerja guru. Jadi hipotesis yang penulis ajukan dapat diterima yaitu ada pengaruh yang signifikan antara supervisi akademik pengawas sekolah terhadap kinerja guru di MI Kecamatan Prambon Nganjuk.

Berdasarkan analisis hasil penelitian menunjukan bahwa hasil yang ingin dicapai dari aktivitas supervisi akademik yang dilakukan oleh pengawas dan adalah berkembang dan meningkatnya kinerja guru dalam menjalankan tugas pokok dan fungsinya sesuai dengan keputusan Mendikbud No. 025/0/1995 Tentang Petunjuk Teknis Ketentuan Pelaksanaan Jabatan Fungsional Guru dan Angka Kreditnya,dan Peraturan Mentri Pendidikan Nasional RI nomor 39 tahun 2009 Tentang pengaturan beban kerja guru dan pengawas serta pedoman pelaksanaan kerja guru dan pengawas sebagai patokan target yang yang ingin dicapai, dan gambaran kinerja empiris di sekolah setelah dilakukan aktivitas supervisi akademik oleh pengawas dan kepala sekolah.

Informasi mengenai indikator kinerja guru ini penting untuk diungkapkan ,karena akan memberikan gambaran secara komprehensif mengenai unjuk kerja (kinerja) dari seorang guru di sekolah. Dengan demikian upaya yang berkaitan dengan pengembangan sumber daya manusia yaitu guru-guru khusunya di MI Kecamatan Prambon akan lebih terarah karena memiliki acuan yang jelas. Dari deskrifsi hasil penelitian diatas dapat dimaknai apabila indikator kinerja guru tidak dirumuskan secara khusus dalam bentuk alat penilaian kinerja guru, maka evektivitas dan efisiensi pengelolaan tugas pokok guru akan sulit diukur.

Gambaran kinerja guru setelah disupervisi nampak ada peningkatan terkait dengan ; disiplin kehadiran guru, kelengkapan administrasi pembelajaran, adanya jaminan proses pembelajaran dan adanya upaya guru untuk membantu kesulitan belajar siswa.

Kehadiran guru di kelas, informasi ini penting untuk diungkapkan mengingat peraturan mentri nomor 39 tahun 2009 tentang beban kerja guru dimana guru wajib mengajar di dalam kelas minimal 24 jam pelajaran perminggu, @=35 menit, sedangkan beban kerja kumulatif bagi guru PNS sesuai penjelasan permen Diknas nomor 39 tahun 2009 tentang beban kerja Guru PNS adalah rata-rata perminggu 37,5 Jam @ =60 menit. Dengan demikian tingkat kehadiran guru di sekolah menjadi tolak ukur jaminan disiplin kinerja guru. Dalam upaya menjamin disiplin kehadiran guru di sekolah maka di MI se Kecamatan Prambon telah diberlakukan check-in dan check-out kehadiran guru dan staf dengan menggunakan timer,sehingga tingkat kehadiran guru dapat dipantau setiap saat.

Kelengkapan administrasi
pembelajaran guru bisa dijadikan indikator tentang kinerja guru, dimana guru wajib menyiapkan perencanaan berupa program untuk kelancaran dalam proses pembelajaran dalam rangka mencapai core business pendidikan di sekolah. Kelengkapan administrasi guru yang harus ada di sekolah berdasarkan intrumen penilaian kinerja guru dari Dirjen PMPTK, meliputi : (1) Standar isi (SK,KD), (2) silabus, (3) Program analisis SK.KD terkai denganmateri pembelajaran, metode, media dan evaluasi, (4) kriteria ketuntasan Minimum (KKM), (5) Program analisis ketuntasan belajar, (6) remedial dan pengayaan (7) program belajar diluar kelas, (8) Dokumen penilaian, dan (9) materi dan media pembelajaran.

Adanya jaminan bahwa proses pembelajaran di kelas akan berjalan dengan baik, informasi ini penting diungkapkan mengingat pengelolaan sekolah efektif yang berbasis standar 
pendidikan nasional ditandai dengan adanya jaminan mutu (quality assurance) terhadap semua aspek yaitu delapan standar dimulai dari standar isi, stan proses, standar pendidik dan tenaga kependidikan, standar kelulusan, standar pengelolaan, standar sarana ,standar pembiayaan dan standar penilaian. Jaminan bahwa proses pembelajaran yang dilakukan guru akan berjalan dengan baik merupakan langkah maju dari system pengelolaan sekolah secara keseluruhan, karena hal ini akan berdampak pada meningkatnya tingkat kepercayaan publik (public accotability) terhadap sekolah pada khususnya dan dunia pendidikan pada umumnya.

Membantu kesulitan belajar anak, informasi ini penting dikemukakan mengingat perlakuan kepada anak yang kesulitan dalam belajar (belum tuntas) sering diskriminatif, anak dikotak-kotak berdasarkan katagori tuntas-tidak tuntas. Padahal hal tersebut kurang baik ditinjau dari sudut pandang psikologis pendidikan, sebab guru perlu menyadari bahwa kesulitan atau ketidak mampuan mungkin oleh anak bisa jadi dianggap aib oleh karenanya sebisa mungkin jangan sampai diketahui oleh teman yang lainnya. Prinsif "kemukakan kebaikan anak didepan temannya dan sembunyikan kekurangan anak dari temannya" barangkali perlu direnungkan kembali.

\section{Kesimpulan}

Kesimpulan dalam tesis ini adalah sebagai berikut: 1) Tingkat keaktifan supervisi akademik pengawas sekolah di MI Kecamatan Prambon Nganjuk adalah baik hal ini dibuktikan dengan fakta empiris dengan indikator pelaksanaan kurikulum yang berlaku. Perencanaan, pelaksanaan dan penilaian proses pembelajaran oleh guru. Pencapaian standar kompetensi lulusan (SKL), standar proses, standar isi, dan peraturan pelaksanaannya. Peningkatan mutu pembelajaran melalui pengembangan model kegiatan pembelajaran, peran serta peserta didik dalam proses pembelajaran secara aktif, kreatif, demokratis, mendidik, memotivasi, mendorong kreatifitas dan dialogis bahwa sebanyak 66 responden yang menjawab baik adalah 27 responden atau (41\%), cukup baik sebanyak 13 responden atau (20\%), kurang baik sebanyak 11 responden atau (17 \%), sangat baik 9 responden atau (13\%) dan sangat kurang baik 6 responden atau (9\%).

2) Tingkat kinerja guru di MI Kecamatan Prambon Nganjuk adalah cukup baik hal ini dibuktikan dengan fakta empiris bahwa dengan indikator kompetensi menyusun rencana pembelajaran, kompetensi melaksanakan proses belajar mengajar, kompetensi melaksanakan penilaian proses belajar mengajar, hubungan antar pribadi dari 66 responden yang menjawab cukup baik adalah 24 responden atau (36\%), kurang baik 20 responden atau (30\%) sangat kurang baik 11 responden atau (17\%), baik 10 responden atau (15\%), sangat baik 1 orang atau $(2 \%)$.

3) Korelasi supervisi akademik pengawas sekolah terhadap kinerja guru di MI Kecamatan Prambon Nganjuk adalah kuat, berdasarkan hasil analisis bahwa nilai korelasi sebesar $r_{x y}=0,757$ yang berarti terletak pada interval nilai 0,60 - 0,79 artinya terdapat korelasi yang kuat antara kualitas supervisi akademik dengan kinerja guru.

\section{Saran}

1) Bagi Kementerian Agama, Peningkatan peran supervisi akademik pengawas sekolah terhadap madrasah binaan dan guru-guru binaan harus mendapat perhatian yang baik dari Kantor Kementerian Agama Kabupaten Nganjuk melalui seksi pendma dengan cara jumlah pengawas sekolah yang kurang memadai perlu ditambah sehingga pembinaan sekolah dan para guru menjadi lebih efektif dan ada program Pembinaan dan pelatihan intensif untuk pengawas sekolah dilakukan setiap semester.

2) Bagi Madrasah, perlu menyediakan ruang kerja pengawas di sekolah masingmasing, sehingga proses pembinaan pada sekolah dan para guru dapat lebih efektif. 


\section{Daftar Pustaka}

Akadum. (1999). Potret Guru Memasuki Milenium Ketiga. Suara Pembaharuan.

(Online).(http://www.suarapembah aruan.com/News/1999/01/220199/ OpEd, diakses 21 Oktober 2015

Arikounto, SuharsImi (2002), Prosedur Penelitian Suatu Pendekatan Praktek, Jakarta: Rineka Cipta.

--(2004). Dasar-dasar Supervisi. Jakarta: PT Rineka Cipta.

Azwar, Sifudin (2001), Metode Penelitian, Yogyakarta: Pustaka pelajar, 2001.

Bungin, Burhan (2005), Metode Penelitian Kuantitatif Jakarta: Kencana.

Hasan, Iqbal Analisis Data Penelitian Dengan Statistik, 24.

Hasibuan, H. Malayu S. P. (2005). Manajemen Sumber Daya Manusia. Jakarta: PT. Bumi Aksara

Irianto, Agus, (2004), Statistik Konsep Dasar dan Aplikasinya Jakarta: Kencana Prenada Media Group.

Kartono, Kartini (1996), Pengantar Metodologi Riset Sosial, Bandung: Mandar Maju

Marzuki, Metodologi Riset, (2006) Yogyakarta: Fakultas Ekonomi UI

Mulyasa (2013). Uji Kompetensi dan Penilaian Kinerja Guru. Bandung: PT Remaja Rosdakarya.

Purwanto, Ngalim. (2012). Administrasi dan Supervisi Pendidikan. Bandung: PT Remaja Rosdakarya.

\footnotetext{
Sagala, Syaiful H. (2010) Supervisi Pembelajaran dalam Profesi Pendidikan: Membantu Mengatasi
}

Siswanto. (2003). Manajemen Tenaga Kerja Indonesia Pendekatan Administratif dan Operasional. Jakarta: Bumi Aksara

Sugiono, (1999), Statistik Untuk Penellitian Bandung: Alfabeta

Sutrisno, Hadi, (1991), Metode Research, Bandung: Pustaka Setia

Usman, Husaini (1998), Metodologi Peneltian Sosial, Jakarta: Bumi Aksara.

Yamin, Martinis (2010). Standarisasi Kinerja Guru. Jakarta: Gaung Persada Press. 